University of Massachusetts Amherst

ScholarWorks@UMass Amherst

2021

\title{
The Legacy of Byzantine Christianity in the Southern Mani Peninsula, Greece, after Imperial Collapse
}

\author{
Rebecca M. Seifried \\ University of Massachusetts Amherst, rseifried@umass.edu
}

Follow this and additional works at: https://scholarworks.umass.edu/librarian_pubs

\section{Recommended Citation}

Seifried, Rebecca M., "The Legacy of Byzantine Christianity in the Southern Mani Peninsula, Greece, after Imperial Collapse" (2021). Rituals, Collapse, and Radical Transformation in Archaic States. 90. https://doi.org/10.7275/w64z-5t32

This Article is brought to you for free and open access by the University Libraries at ScholarWorks@UMass Amherst. It has been accepted for inclusion in University Libraries Publication Series by an authorized administrator of ScholarWorks@UMass Amherst. For more information, please contact scholarworks@library.umass.edu. 


\title{
The Legacy of Byzantine Christianity in the Southern Mani Peninsula, Greece, after Imperial Collapse
}

\author{
Rebecca M. Seifried \\ University of Massachusetts Amherst, Amherst, MA 01003-9275, USA \\ ORCID: https://orcid.org/0000-0002-4372-2164, email: rseifried@umass.edu
}

\section{Citation}

Seifried, R.M. 2021. "The Legacy of Byzantine Christianity in the Southern Mani Peninsula, Greece, after Imperial Collapse." In Rituals, Collapse, and Radical Transformation in Archaic States, edited by Joanne M. A. Murphy, pp. 56-76. New York: Routledge.

\begin{abstract}
Religion is one of the many potential mediums for emphasizing ethnic difference and highlighting group membership. Particularly in mountainous landscapes, which are difficult for imperial or state powers to control, religion may be a key means of asserting peripherality. The residents of the Mani Peninsula, Greece, converted to Orthodox Christianity during the reign of the Byzantine Empire and maintained this religious affiliation even after Byzantine collapse in $1463 \mathrm{CE}$, when the region came under Ottoman and, later, Venetian rule. This study reviews the research on Mani's Byzantine churches to date - much of which is published in Greek - and presents new interpretations of the religious practices of the Byzantine and post-Byzantine communities of Mani. This case study sheds light on the role of religion in rural communities and the potential reasons for religious continuity in peripheral landscapes during periods of social transformation. In particular, the firm adherence of Mani's residents to Orthodox Christianity emphasized their ethnic difference from the ruling authorities and simultaneously undermined these authorities' ability to assert hegemonic power in the region.
\end{abstract}

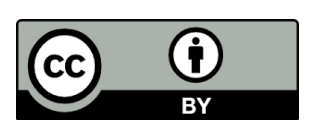

(C) 2020. This manuscript version (post-print) is made available under the CC BY 4.0 license: https://creativecommons.org/licenses/by/4.0/ 
This case study provides an opportunity to explore, through the lens of religious practice, how rural communities experience periods of collapse and regeneration. The Mani Peninsula is the mountainous central finger of the Peloponnese and its southernmost projection into the Aegean Sea (Figure 4.1). Over the past two millennia, Mani and the wider Peloponnese were part of a series of succeeding empires and kingdoms. The Byzantine and Ottoman Empires ruled Mani for the longest stretches of time before it fought for independence in 1821, but within these eras were hiatuses when other powers took control: first, when the Frankish principalities arose in the 1200s, and then again when the Republic of Venice conquered the Morea in 1685 (Table 4.1). Today, a rich and diverse body of religious architecture - Orthodox, Catholic, Islamic - still exists throughout the Peloponnese, a reminder of the hegemonic influence that these powers were able to assert and a sign of the broader cultural and religious integration that took place between local populations and the ruling powers (e.g., Ameen 2017; Sanders 2015).

Mani, however, is a unique case when compared with the rest of the Peloponnese. One reason is that the region is home to a remarkable number of Byzantine cultural monuments, which consist primarily of hundreds of small, provincial churches. Another is the fact that all of this religious architecture belongs to the denomination of Eastern Orthodox Christianity. Not a single Catholic or Islamic place of worship is preserved in the settlements of Mani, despite the fact that it was ruled by a Catholic power (the Republic of Venice) for 30 years and by an Islamic power (the Ottoman Empire) for far longer. Limited documentary evidence - including the supposed foundation of a "Turkish" settlement at Tourkovrysi and the inhabitants' murder at the hands of local residents shortly thereafter (Komis 2005:320) - suggests that if any such places had been built, they must have been promptly destroyed. 


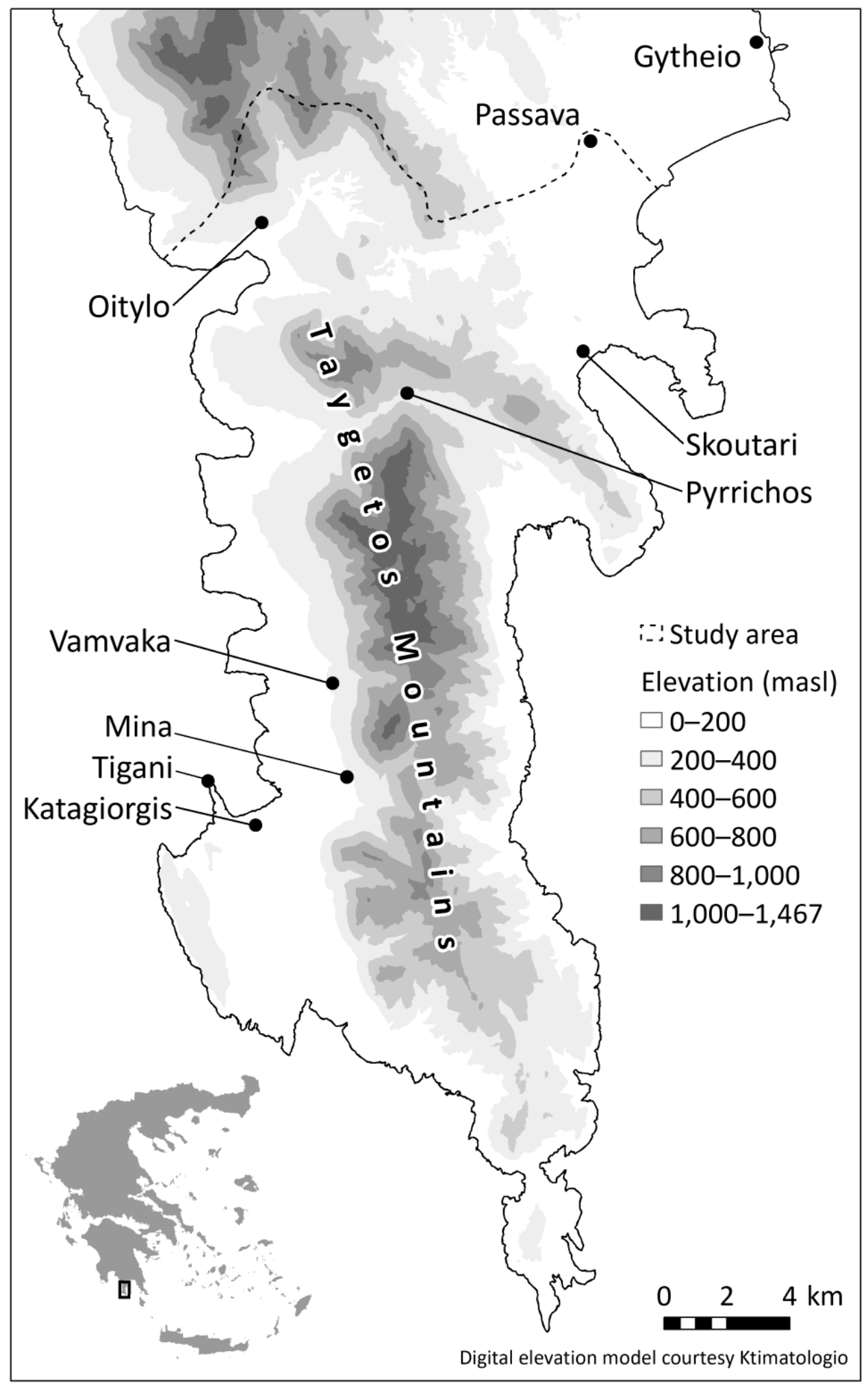

Figure 4.1. The southern Mani Peninsula, Greece, highlighting places mentioned in the text. 
Table 4.1. Chronology of ruling powers in the Peloponnese, Greece, with period designations used in this paper.

\begin{tabular}{lll}
\hline Years (CE) & Dominant Political Power & Period Designation \\
\hline $324-843$ & Byzantine Empire & Early Byzantine \\
$843-1204$ & Byzantine Empire & Middle Byzantine \\
$1204-1261$ & Frankish principalities & Middle Byzantine \\
$1261-1463$ & Byzantine Empire & Late Byzantine \\
$1463-1685$ & Ottoman Empire & First Ottoman \\
$1685-1715$ & Republic of Venice & Second Ottoman \\
$1715-1821$ & Ottoman Empire & Second Ottoman \\
$1821-1950$ & Greece & Early Modern \\
$1950-$ present & Greece & Modern \\
\hline
\end{tabular}

Reading through other case studies on societal transformation, it is difficult to find a parallel that helps make sense of the situation in Mani over the last two millennia. The current approaches to "societal transformation" (that is, the process of collapse and regeneration; Faulseit 2015) tend to favor a system-wide perspective, seeking to explain the "how" of social change rather than the "why" of specific case studies. Within archaeology, the most widely applied models that have come out of this perspective include declining marginal returns, political cycling, general systems theory, and resilience theory (Faulseit 2015; Schwartz 2006). Recent studies have stressed that collapse does not necessarily mean the end of a culture or population and that, on the contrary, some elements of the previous system may very well persist into the next. Some also point out that elites and rural populations experience collapse very differently, with elites feeling the disruption of political and economic systems more acutely (Middleton 2017:18). While these latter two points do describe the case of Mani, overall the system-wide models are an awkward fit because they tend to focus on urban centers, regional polities, or places that are otherwise critical to the functioning of the state. Mani is, and never was, such a place. Instead, it is the kind of remote and self-sustaining, peripheral region that is described in the core/semi-periphery/periphery model of world-systems theory (Wallerstein 1974). 
In a compelling article about the modern, globalized world-system, Kuecker and Hall $(2011: 28)$ argue that communities living in peripheral regions are more resilient than those closer to the core, inherently equipped to sustain systemic transformation because of the autonomy granted by their (both literal and metaphorical) distance from official state structures. In the modern world, peripheral communities are those indigenous peoples who have managed to sustain some elements of their pre-state identities or adapt new elements in ways of their own choosing through the process of "negotiated peripherality" (Kardulias 2007:55). Looking back in time, we can imagine that different kinds of peripheral communities must have existed, which weathered systemic transformation in similar ways. Possible examples from the literature on societal transformation include the middle Euphrates Valley in Syria (Cooper 2006) and the Wari frontier (Williams and Nash 2016). I argue that the people living in Mani during the transition to Ottoman rule constituted precisely these kinds of resilient, peripheral communities.

The aim of this paper is to review the current state of knowledge about religious practice in Mani over the past two millennia, particularly in light of the region's peripheral status to the powers that ruled it. I prefer to think of religious practice - and ritual, more broadly - as a local strategy for fostering cooperation and collective action, rather than a deliberate tool that external powers use to control a region (see Feinman 2016). In his analysis of the relationship between architecture and ritual, Blundell Jones (2016:3) reminds us that "buildings and activities tend to reinforce each other... Buildings provide prompts for action and frameworks to define relationships with fellow human beings in forming societies or communities." Churches, like any buildings, are places where the ritual actions of the liturgy or annual saint day celebrations (panayiria) reinforce social connections. Thus, the unending cycle of ritual practices, the decisions to allocate community resources to maintain religious infrastructure, and the personal commitment to particular belief systems can be seen as parts of a community-strengthening strategy that enabled resilience and sustained survival through a period of collapse and regeneration. In turn, this strategy was made possible in part because of the region's distance from the ruling authority. 
In addition to summarizing earlier research on the churches of Mani, this paper presents new insights from a project that used Geographic Information Systems (GIS) to document the Byzantine and Ottoman-period settlements in the southern half of the peninsula (Seifried 2016). The northern edge of the study area (totaling about $350 \mathrm{~km}^{2}$ ) followed a pass leading through the central Taygetos Mountains, with the town of Oitylo and the fortress of Passava marking the northwestern and northeastern edges of the region, respectively (see Figure 4.1). Between 2014 and 2016, all extant settlements and built features were documented using remotely sensed imagery, published sources, and field reconnaissance. Additionally, Ottoman tax registers from the $16^{\text {th }}$ to $18^{\text {th }}$ centuries were studied in order to learn about settlement continuity and abandonment, gather data about population, and understand more about the Ottoman administration in the region. The evidence for religious practice in Mani is presented here in three sections: (1) church construction and use, (2) patronage, design, and local artisanship, and (3) professed religious belief. The discussion turns to the issue of how religion might be used as a tool for maintaining and emphasizing a pre-collapse identity, as well as for undermining a new state's power in a given region.

\section{Church Construction and Use}

The total number of Orthodox churches in Mani is not known for certain. Research has tended to focus on individual churches or groups of monuments defined either by chronology, architectural style, or the decorative elements they contain. Excavations and architectural surveys have been carried out at the most spectacular churches in Mani, and the reports from these studies can be found in numerous Greek journals, proceedings volumes, and monographs (e.g., Drandakis 1995, 2002, 2009). In recent decades, the Hellenic Ministry of Culture has renovated the most important religious monuments and organized a broader program called the "Network of Mani Museums" (NMM), which resulted in an exhibition on "Tales of Religious Faith" in the Pikoulakis tower museum in Areopoli 
and the publication of two associated books (Hellenic Ministry of Culture 2004, 2005).

As part of the NMM project, a GIS-based architectural survey was conducted throughout the peninsula to document its standing architectural heritage.

Researchers reportedly registered over 1,400 churches in both the northern and southern parts of Mani (Kalamara et al. 2009:370). To date, the NMM mapping project has resulted only in a series of maps of the peninsula, which are displayed in the exhibition and published in the accompanying books. The maps depict the locations of the churches at a very coarse resolution and group them into broadly defined time periods. ${ }^{1}$ Unfortunately, the geospatial data from the NMM project is not currently available to researchers.

Through the field research described above, a total of 494 churches dateable to the Early Byzantine through Modern periods were digitized in the study region (Figure 4.2; for methods, see Seifried and Kalaycl 2019). The dating of these churches was verified through field reconnaissance or cross-referencing with published sources. Another 136 churches were marked on the NMM maps but could not be verified through another source. Nevertheless, because the maps contain chronological information, these churches are included in the counts reported throughout this paper in order to give a fuller picture of the broad chronological patterns of church construction and use.

${ }^{1}$ The time periods used in the NMM maps are: Early Christian (AD $330-9^{\text {th }}$ century), Middle to Late Byzantine ( $9^{\text {th }}$ century to 1453 ), early Post-Byzantine (1453-1600), later Post-Byzantine (1600-1830), and modern (1830-early $20^{\text {th }}$ century). 


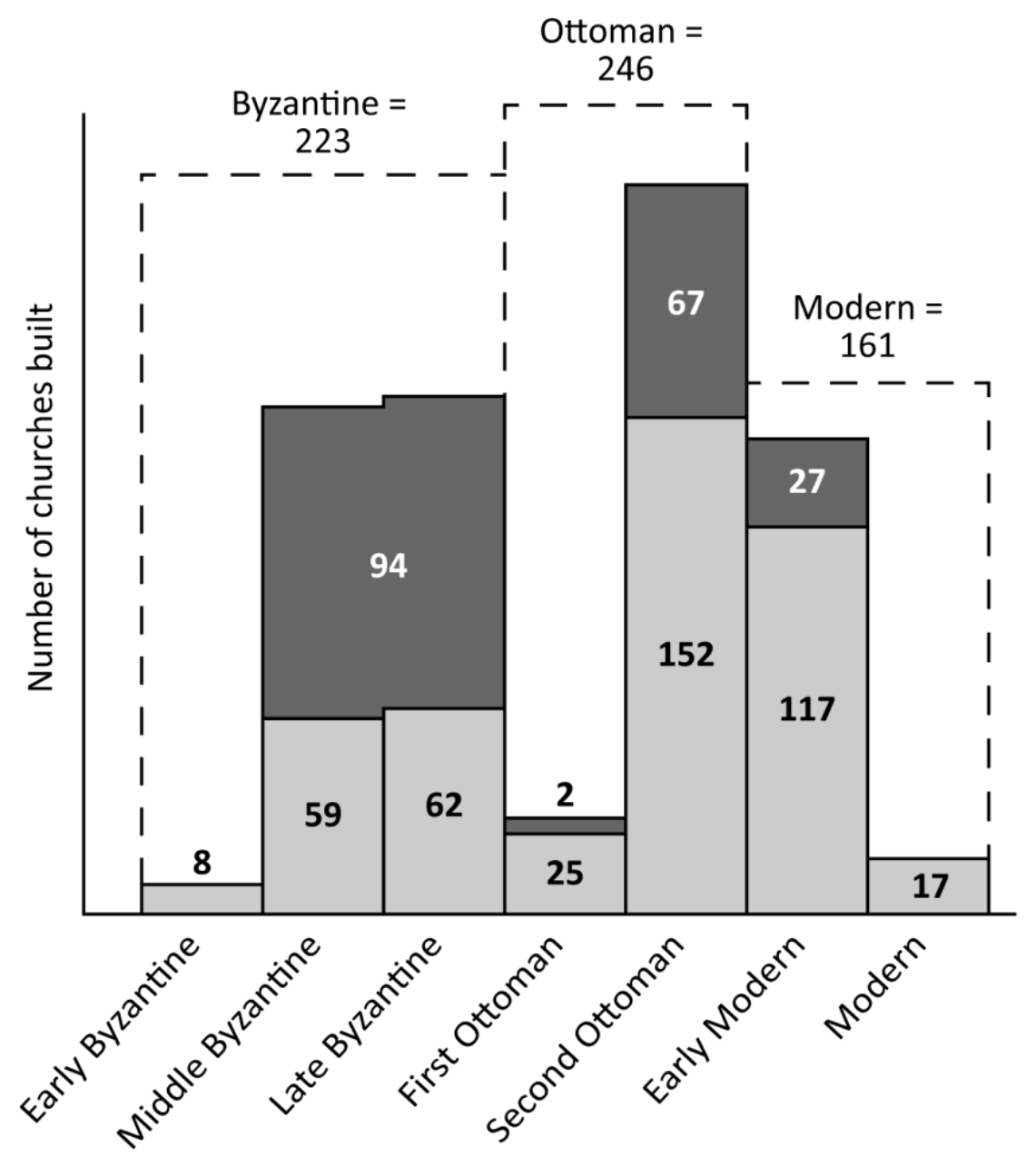

Figure 4.2. Number of churches founded in each period. Light gray represents churches documented through fieldwork or cross-referenced in published sources; dark gray, churches marked on the NMM maps that could not be verified. 


\section{Churches built in the Byzantine periods (324-1463 CE)}

Churches dated to the Byzantine periods have received the lion's share of scholarly attention. The earliest studies that brought light to Mani's Byzantine churches were conducted by Ramsay Traquair (1908) and Arthur H. S. Megaw (1932). Both authors focused on the church of Agios Theodoros in Vamvaka, the only monument they were able to precisely date, thanks to an inscription that commemorated its founding in 1075. They believed that Mani had been a pagan land until the reign of Basil I the Macedonian in 867-886 (Megaw 1932:139; Traquair 1908:210) - a legend put forth by Basil's grandson Constantine VII Porphyrogenitus (1985:232-250) and spread through various later sources (e.g., Finlay 1877:424). As a result, they mistakenly believed that the earliest churches in Mani dated from the $10^{\text {th }}$ to the late $12^{\text {th }}$ centuries. These studies set the tone for the research that would follow, which framed Mani as a region intrinsically tied to the Byzantine capital at Mystra - "a separate entity, provincial and conservative" in comparison to the imperial seats at Athens, Corinth, and Thebes (Megaw 1932:161).

Interest in the region's religious monuments took off in the 1960s, when excavations began at several Early Byzantine basilicas. The best-known of these is the basilica at Tigani, which the excavators originally dated to the $7^{\text {th }}$ century (Drandakis 1966 and subsequent reports through the 1980s; Gkioles 2008). ${ }^{2}$ Including Tigani, a total of eight religious monuments within the study area have been tentatively dated to the Early Byzantine period, pushing the supposed $9^{\text {th }}$ century "Christianization" of Mani back to as early as the $5^{\text {th }}$ century (see reports on these churches by Drandakis and colleagues in Praktika tes en Athenais Archaiologikes Hetaireias and the updated catalog in Mexia 2011).

The Middle and Late Byzantine churches are far more numerous, with 59 churches that can be dated securely to the Middle Byzantine period and 62 to the Late Byzantine period (see Figure 4.2). Another 94 churches were built at some point during this phase but cannot be dated more precisely. Broadly, this reflects an

2 Recent scholarship has argued that the date of the Tigani basilica should be shifted to the $10^{\text {th }}$ or $11^{\text {th }}$ century (Mexia 2015). 
increased pace of church building over the $10^{\text {th }}-15^{\text {th }}$ centuries, with an average of 35 churches built every century compared with the two per century over the course of the Early Byzantine period (Table 4.2).

Table 4.2. Yearly Average Rate of Church Construction.

\begin{tabular}{llll}
\hline Period & Churches built & Years in period & Churches built per year \\
\hline Modern & 17 & 69 & 0.25 \\
Early Modern & 144 & 128 & 1.13 \\
Second Ottoman & 219 & 136 & 1.61 \\
First Ottoman & 27 & 222 & 0.12 \\
Middle-Late Byzantine & 215 & 620 & 0.35 \\
Early Byzantine & 8 & 519 & 0.02 \\
\hline Total & 630 & 1,694 & 0.37 \\
\hline
\end{tabular}

The detailed catalogs of these churches compiled by Drandakis (1986) and Mexia (2011) show that church construction in Mani reached its height in the $13^{\text {th }}$ century, despite the fact that the $11^{\text {th }}$ century is often considered to be the apogee of the Byzantine Empire from a political, military, and economic standpoint. In the final two centuries of Byzantine rule, relatively few churches were founded (see Mexia 2011:233).

Altogether, there are approximately 223 churches dated to the broad length of time between the beginning and ending of Byzantine rule in the southern half of the Mani Peninsula, making this one of the richest areas of Byzantine cultural heritage in Greece. The excellent preservation of the structures has been attributed to Mani's isolation and environmental stability during the later periods of Ottoman and Venetian rule (Mexia 2016:n. 3), but it also seems that the number of churches was disproportionately high from the start. It has been estimated that about 2,000 Byzantine churches were built in the area that comprises the modern state of Greece (Chatzidakis 1981:380). If accurate, this would mean that Mani's churches constitute an extraordinarily large share of the total Byzantine religious infrastructure in Greece. 


\section{Churches built in the Ottoman to Modern periods (after 1463 CE)}

Compared with the Byzantine churches, less is known about the churches that were built during and after the Ottoman periods and later. Nevertheless, they make up the greater part of the extant religious monuments in Mani. DeliyianniDori's $(1994,2005)$ brief reports summarize the archaeological work that has been conducted - particularly since the 1990s - on post-Byzantine churches throughout the peninsula. These reports indicate that the decline in church-building that took place at the end of the Late Byzantine period continued for several centuries after the transition to Ottoman rule. According to the research team, no new churches were built immediately after the transition in the second half of the $15^{\text {th }}$ century, but the pace picked up again in the $16^{\text {th }}$ century. My research in the southern half of the peninsula, in combination with the NMM mapping project, documented a similar pattern of church construction. A total of 27 churches were built in the southern Mani Peninsula in the First Ottoman period, 219 in the Second Ottoman period (including churches founded during the brief 30-year period of Venetian rule), 144 in the Early Modern period, and 17 in the Modern period (see Figure 4.2). Examining the average rate of church construction over time underscores the rapid surge in construction that took place in the past three centuries, reaching a maximum pace of 1.61 churches built every year in the Second Ottoman period (see Table 4.2). One result of this construction boom is that the extant churches dating to the $18^{\text {th }}$ and $19^{\text {th }}$ centuries far outnumber those founded during the entire 12 centuries of Byzantine rule.

It is worth noting that the small number of publications on Mani's postByzantine religious monuments reflects the broader situation in Greece as a whole, where later phases have traditionally received little attention because they were considered less important than older, more "ancient" phases. Byzantine archaeology has only recently expanded beyond its initial focus on churches as archaeologists have begun using field survey and household excavation to investigate other aspects of lived landscapes (e.g., Athanassopoulos 2016; Cassis et al. 2018; Gregory 2013; Papantoniou and Vionis 2017; Vionis 2012; Vroom and Kondyli 2015). Still, the bias against post-Byzantine materials is a continuing 
problem in Greece and is the main contributing factor to the lack of research on Mani's Ottoman, Early Modern, and Modern religious remains.

\section{Church use over time}

The sharp drop-off in new church construction that began in the $14^{\text {th }}$ century and continued into the First Ottoman period could be read as a sign that the people living in Mani after Byzantine collapse invested fewer resources in their religious landscape. Indeed, the popular conception of this period is that people suffered under the regulations of the new Ottoman administration: they faced heavier taxes, increased stress from sickness and climate change, and population decline due to migration. Panayotidi (2005a:194) called it a "period of particularly intense deprivation," and Kalopissi-Verti (1999:204) suggested that the decline in church building reflected the "impoverishment of the inhabitants of the region, who could rarely afford to have churches built and painted."

Data collected during field reconnaissance about church use paint provide different insights into the situation at this time (Figure 4.3). Looking only at those churches that can be dated definitively to the Late Byzantine $(n=123)$ and First Ottoman ( $n=129$ ) periods, it appears that there was less of a change in the religious landscape after Byzantine collapse than might be expected from the prevailing historical narrative. In fact, it is likely that even more churches were in use post-collapse, but the exact abandonment date of many of the Byzantine structures is unknown. By the Second Ottoman period, the number of churches in use had increased substantially, owing primarily to the foundation of new churches. The broader pattern of church use over the course of the past millennium underscores this overall trend: increasing from 223 churches in the Byzantine periods to 422 in the Modern periods.

Rather than disrupt the religious landscape of Mani, the onset of Ottoman rule appears to have provided relative stability, allowing the religious landscape to be maintained at pre-collapse levels. Roughly the same number of churches were in use before and after this transition, and most of the churches in use during the First Ottoman period were actually maintained from earlier centuries. While the pace of 
new church construction slowed in the centuries immediately following Byzantine collapse, local residents may have redirected their resources toward church maintenance - a shift toward a less costly form of investment that may very well have been necessitated by the difficult economic situation of the time.

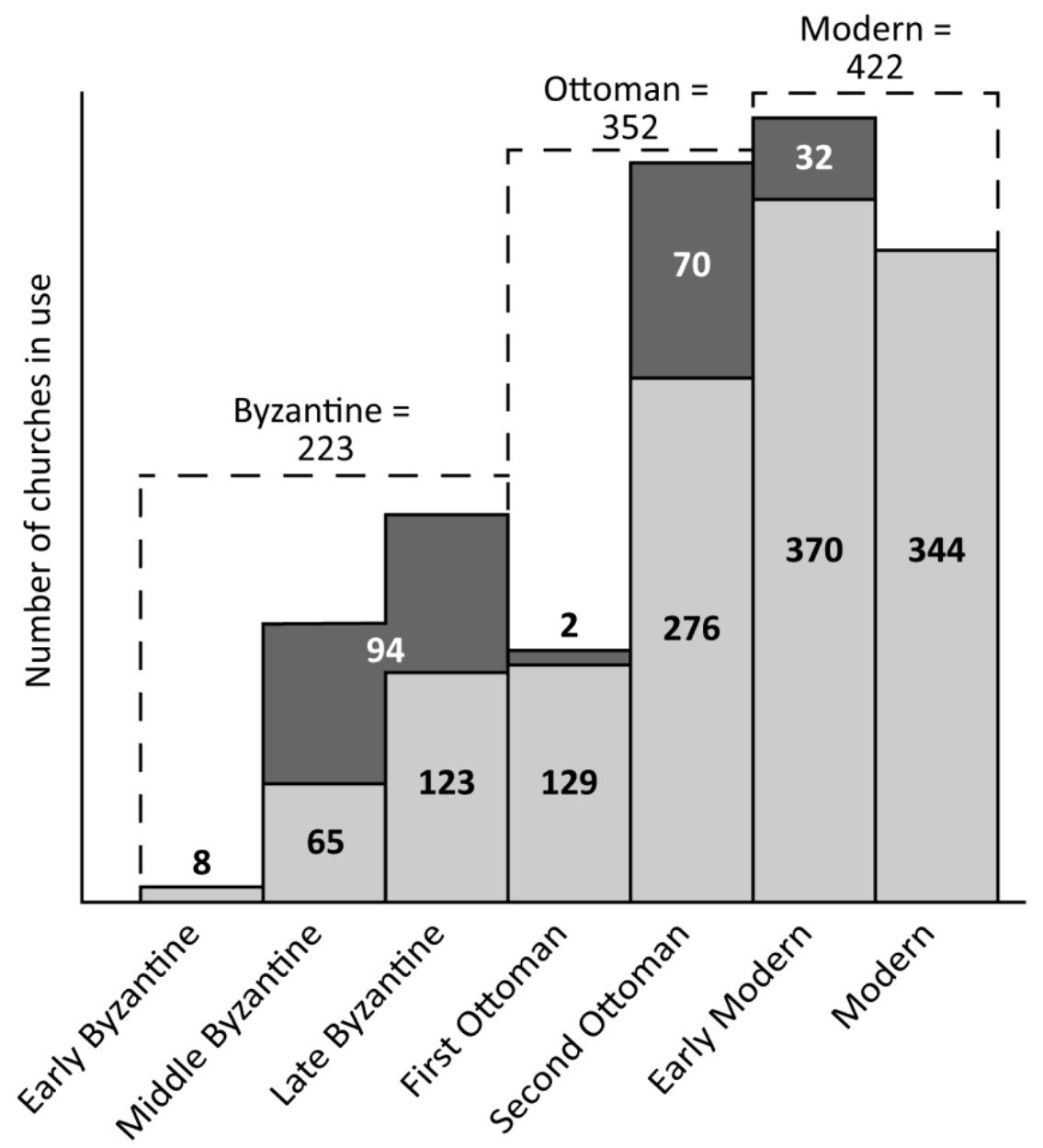

Figure 4.3. Number of churches in use in each period. Light gray represents churches documented through fieldwork or cross-referenced in published sources; dark gray, churches marked on the NMM maps that could not be verified. 


\section{Patronage, Church Design, and Local Artisanship}

Studies of church patronage provide important insights into the socioeconomic status and social organization of the people living in Mani, particularly in terms of who donated resources to the churches and decorated their walls, where the donors came from, and how the donors were connected to the surrounding communities. A key source is a group of roughly 30 preserved dedicatory inscriptions, which provide details about the system of patronage and how it changed over the course of the Byzantine periods (Kalopissi-Verti 2003; see also Katsafados 2015). Whereas individual donors were most common in the rest of the Byzantine world, patronage in Mani comprised a mixture of individual and communal donations, which has been taken to indicate "the wide, almost universal, participation of ordinary people" in the religious landscape (Kalopissi-Verti 2005:106). Further, the simple grammar, misspellings, and evidence of the local dialect in the dedicatory inscriptions points to the "low standard of learning and literacy of donors, of craftsmen and of the public" (Kalopissi-Verti 2003:349) - a hint at the relative poverty and isolation of the region in comparison with other Byzantine territories.

Studies of church decoration and local artisanship echo this interpretation. Throughout the Byzantine and Ottoman periods, architectural façades, wall paintings, woodcarvings, and sculptures were most frequently crafted in a provincial or "folk" style (Figures 4.4 and 4.5). Local "workshops" - most likely made up of local individuals whose main occupation was farming - were responsible for designing and decorating many of the churches in the region (Mexia 2016:1112; Panayotidi 2005a:208-209). Only a few of Mani's better-financed churches were decorated in ways that reflect the dominant imperial style or featured work from renowned artisans of their time (Figures 4.6 and 4.7). Byzantine churches in this category contained sculptures crafted by the workshop of Niketas the marbleworker (see Drandakis 2002), incorporated the cloisonné masonry and decorative brickwork of the "Helladic School" (Mexia 2016), and boasted wall paintings "sponsored by donors who represent the central authority or are somehow connected to it" (Kalopissi-Verti 1999:195). Likewise, in the Ottoman periods, most 
churches were simple constructions decorated in a "folk" style, and only select examples featured the work of traveling artisans. A few larger, more costly constructions were built to operate as monasteries, parish churches, or churches for exclusive use of the powerful families that arose in the $18^{\text {th }}$ and $19^{\text {th }}$ centuries (Drandakis et al. 1993:1-4).
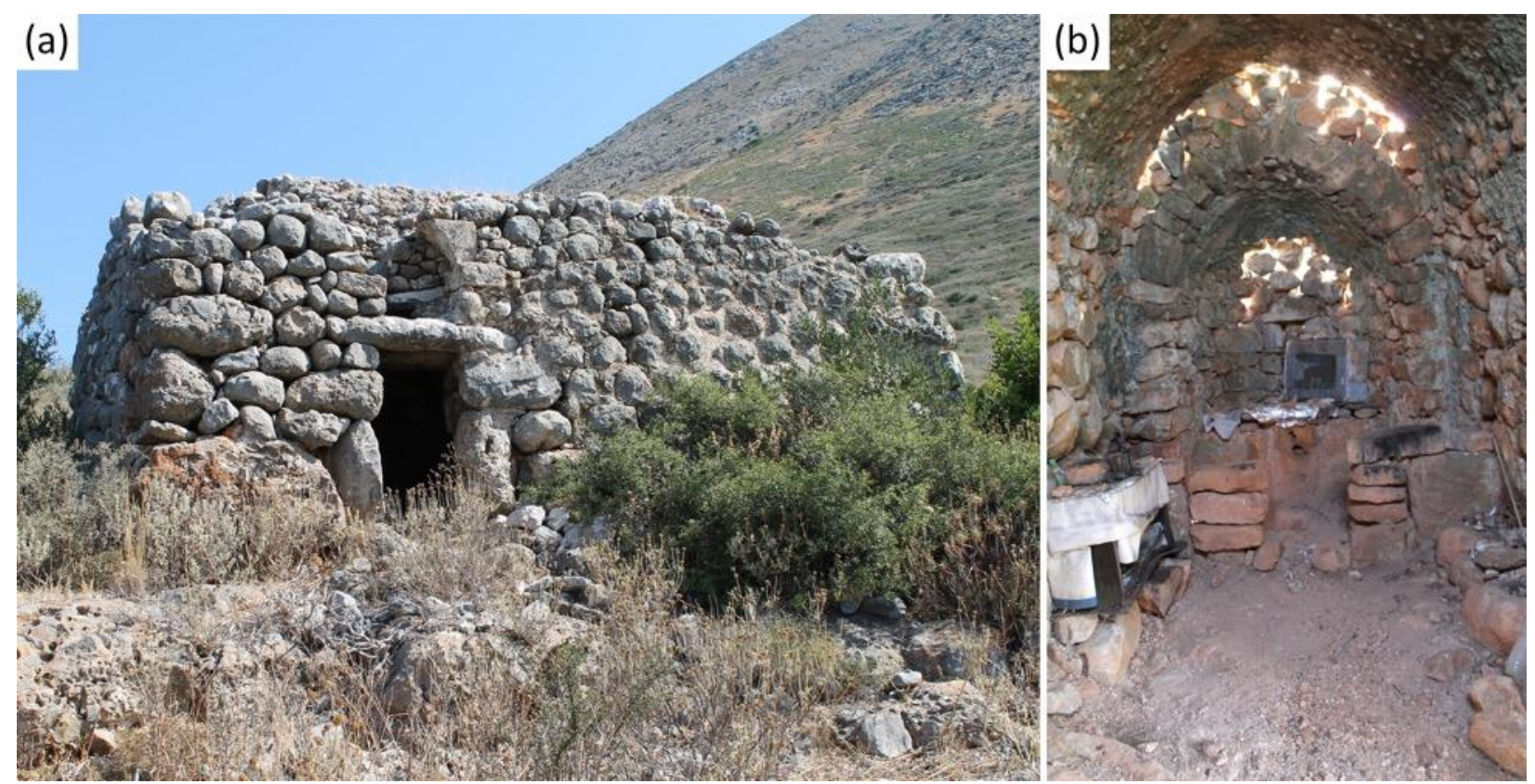

Figure 4.4. Example of a typical Byzantine-period church near Mina: (a) exterior from the southwest; (b) interior. 

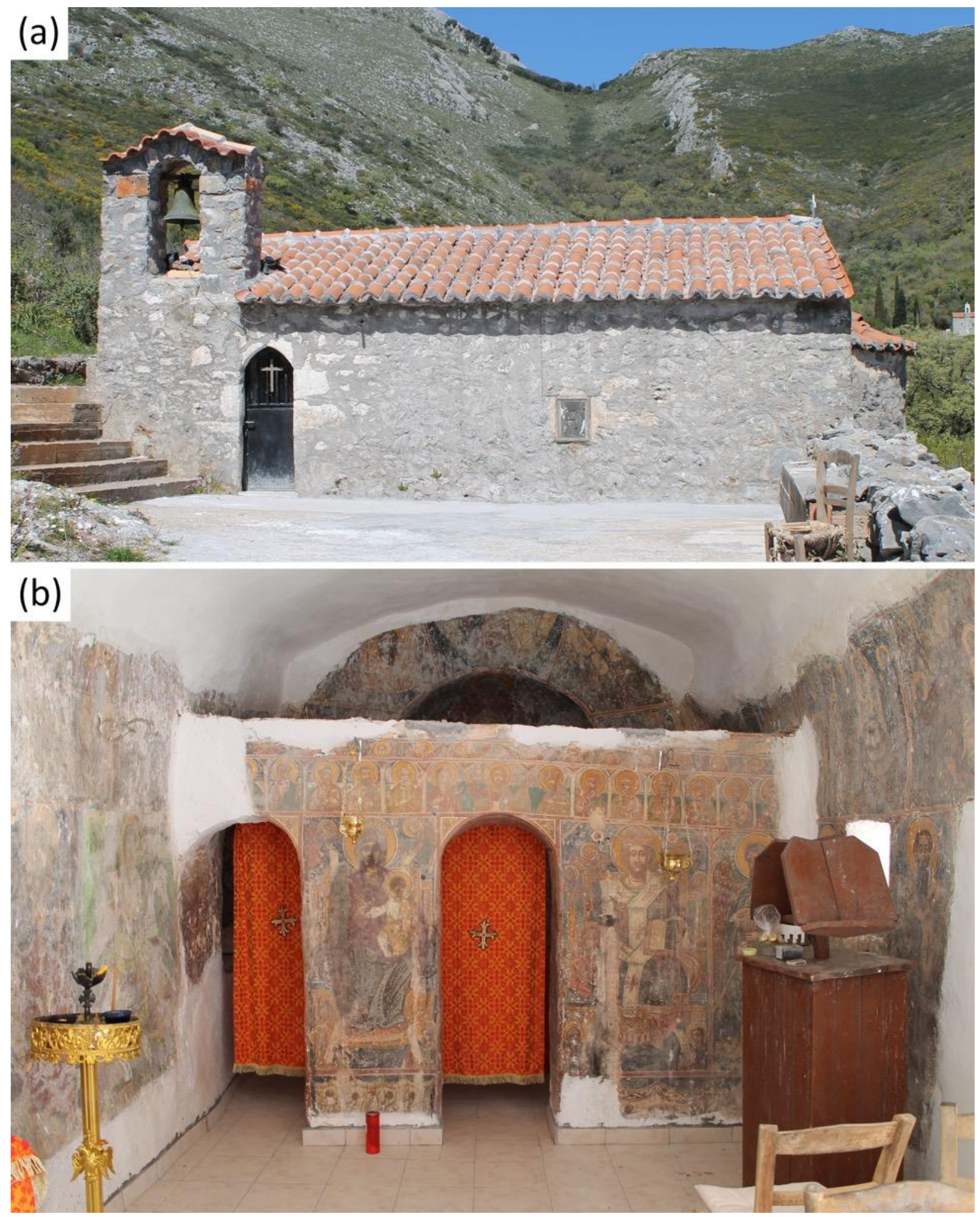

Figure 4.5. Example of a typical Ottoman-period church, Agios Georgios in Pyrrichos (18th c.): (a) exterior from the south; (b) interior. 


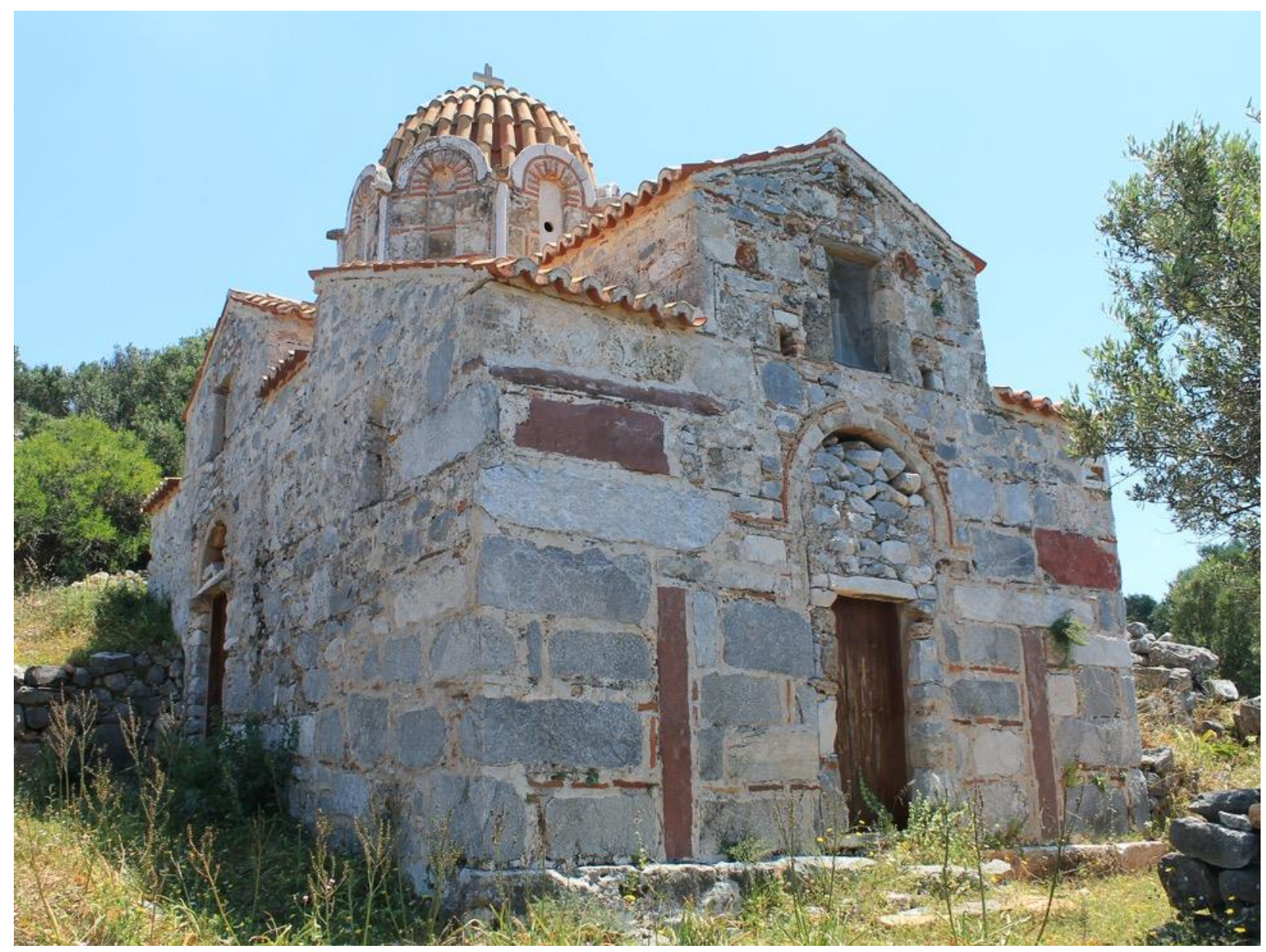

Figure 4.6. Example of a well-financed Byzantine-period church, Episkopi in Katagiorgis (12th c.), exterior from the northwest. 
(a)

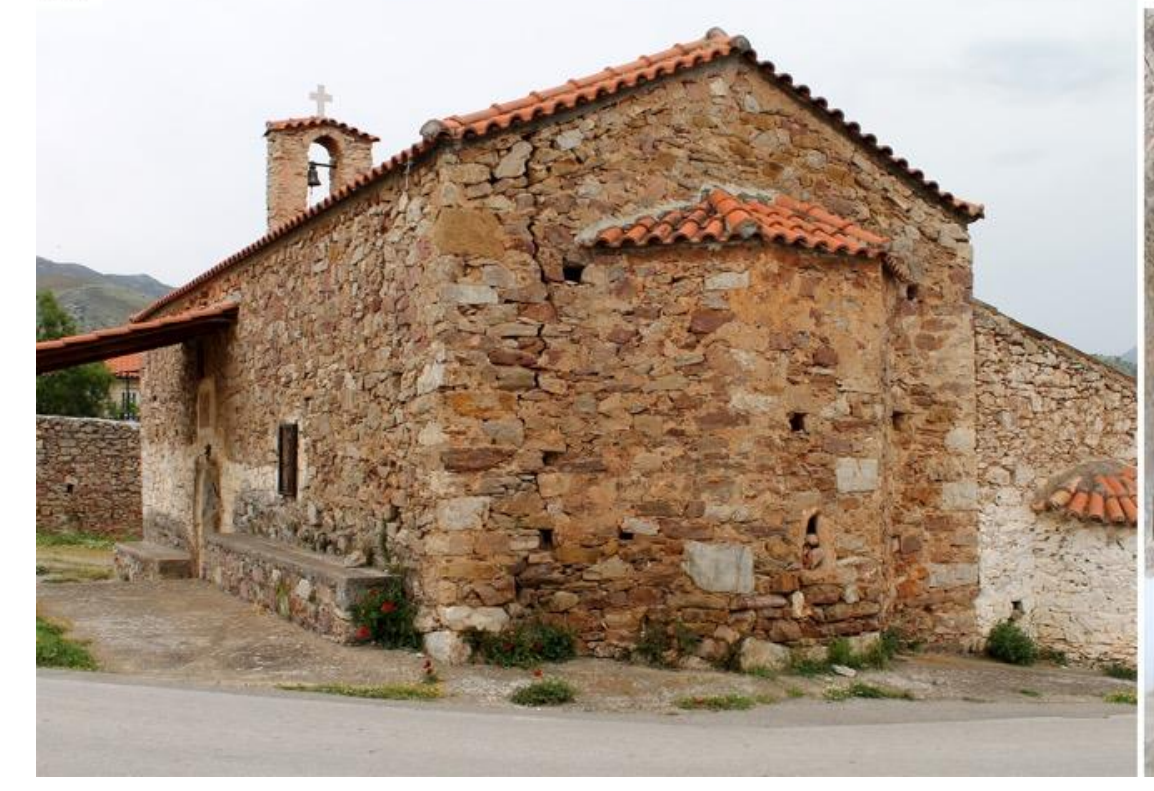

(b)

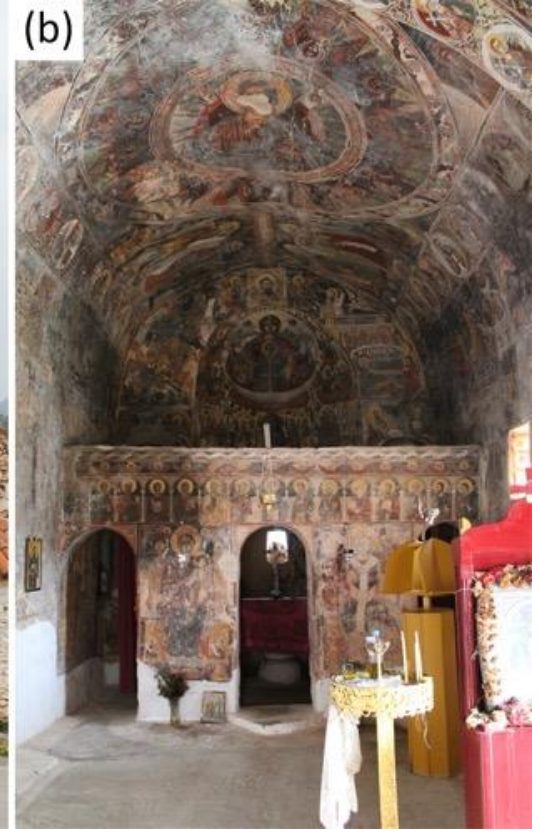

Figure 4.7. Example of a well-financed Ottoman-period church, Agios Ioannis Chrysostomos in Skoutari (18th c.), with signed and dated wall paintings by an artisan from northern Mani: (a) exterior from the southeast; (b) interior.

Scholars have suggested that this evidence of church sponsorship and decoration points to a relatively low level of social stratification and widespread communal participation in the religious landscape over the course of the Byzantine and Ottoman periods (e.g., Kalopissi-Verti 2003:345); however, the lack of excavations of domestic contexts makes it difficult to form definitive conclusions on this matter. Further, most of the research on the connection between churches and village life has focused on Byzantine times (e.g., Gerstel 2015), with little attention paid to the Ottoman and later periods. Still, it is clear that the deep connection between Christian churches and the rural communities of Mani has continued well into the present day. Social stratification certainly increased in later centuries (e.g., with the rise in powerful family clans; see Andromedas 1976:201-203), but simple churches continued to be built at an ever-increasing pace. More elaborate structures, which acted as canvases upon which the powerful could illustrate their wealth and prestige, remained less common. 


\section{Professed Religious Belief}

Conversion to Islam was a widespread phenomenon throughout the Ottoman Empire that continued, in Southeastern Europe at least, until the late $18^{\text {th }}$ century (e.g., Kiel 1999; Minkov 2004). In addition to being a matter of personal faith, conversion brought economic benefits, including exemption from the poll-tax (cizye) and the right to claim monetary compensation (kisve bahası). In many cases, the very communities in which converts lived "stood much to gain from having one of their own in the midst of what was effectively an early-modern superpower" (Graf 2014:148). Given these benefits, one might expect that the residents of Mani also converted, at least occasionally, to Islam. Nevertheless, the current evidence suggests that this was a rare phenomenon.

Ottoman tax registers provide a unique glimpse into the broad religious affiliation of Mani's residents shortly after Byzantine collapse. Documents known as tahrir defterleri were periodically compiled for each Ottoman province for the purpose of recording estimates of agricultural production; in turn, this information was used to assess taxes on each family or township (for an overview, see Coşgel 2002). Several tahrir defterleri covering the territory of Mani are preserved in the Başbakanlık Osmanlı Arşivi (Ottoman Archives) in Istanbul, including a document from 1715 CE (TT878), the year the Ottoman Empire reconquered the Peloponnese from the Republic of Venice (Seifried 2016:119-127). ${ }^{3}$ Included among a list of estates in the northeastern part of Mani are the names of two individuals who had recently converted to Islam and taken Muslim names: İbrahim Karacan and Abdülkerim veled-i Abdülkerim.

This reference is a rare textual account of a resident of Mani converting to Islam during the reign of the Ottoman Empire. ${ }^{4}$ It is particularly striking because the two individuals lived north of the Taygetos Mountains in an area that is

\footnotetext{
3 These records are being studied in collaboration with Dr. Elias Kolovos and will be published separately. The translation here is courtesy Dr. Elias Kolovos.

${ }^{4}$ It is likely that other conversions did take place in Mani: for example, oral history recounts the forced conversion to Islam of a member of the powerful Mavromichalis family in the $19^{\text {th }}$ century (Andromedas 1976:204).
} 
physically and culturally more closely connected to the Peloponnese than it is to the rest of Mani. The isolated reference in TT878 suggests that conversion was an uncommon phenomenon in Mani. Lending weight to this interpretation is the lack of architectural remains of mosques outside the Ottoman fortresses of Passava and Kelepha. This situation contrasts sharply with the inter-faith religious landscape that arose in Mistra and its surrounding villages, which were former strongholds of the Byzantine Empire and yet had several mosques by the $17^{\text {th }}$ century (see account in Çelebi 2011 [1685]:330-338).

\section{Discussion}

Most of the research on Mani's religious landscape has concentrated on the foundation dates and decoration of its many Byzantine churches. New insights into the churches' use lives and the religious adherence of local residents show that Orthodox Christianity continued to play a critical role in the day-to-day lives of residents - not only when the Byzantine Empire was at its height, but also after Byzantine collapse. Mani is a unique case when compared with other parts of the Peloponnese, where a more complex and nuanced religious fabric developed, and where multiple faiths were represented in the religious infrastructure that was built and maintained. The adherence to Orthodox Christianity in the southern Mani Peninsula speaks to the region's separation but also hints at how religion can be used to undermine the power of a ruling state.

The case study presented here illustrates some of the possible effects of a political power transition on the religious landscape of a rural region where its inhabitants actively nurtured their pre-collapse religious identity. These include:

1. The increase in the construction of (pre-collapse) religious infrastructure, depending on resources available to finance new constructions;

2. The continued use of pre-existing religious infrastructure and, if necessary, the redirection of resources toward maintaining older structures;

3. The sponsorship and decoration of religious infrastructure reflecting the involvement of the broader local community, such as communal dedications, 
the use of local artisanal workshops, or the employment of vernacular or "folk" designs and decorations;

4. The use of popular pre-collapse styles as a way of enhancing elites' prestige among the local community;

5. Limited religious conversion, and/or occurrence at lower rates than in other parts of the new ruling state's territory.

The collapse of the Byzantine Empire and the transition to a new ruling state did not have an immediate impact on the religious landscape of the southern Mani Peninsula. On the one hand, this may have been because there were few economic resources available to local residents, and their efforts seem to have been directed toward the preservation of pre-existing churches. On the other hand, the stability that characterized the religious landscape after the transition could be seen as a reflection of the locals' continued adherence to their pre-collapse religious identity.

Other areas of Greece experienced similar trajectories immediately after the transition. Writing about the island of Limnos, for example, Lowry concluded that:

... pre-Ottoman practices in the areas of administration, military practices, church and monastic life, as well as agriculture and taxation were still clearly identifiable on Limnos as late as 1519. There can be little doubt that in this period the Ottoman presence was little more than a veneer superimposed on an island whose inhabitants, religion, language, and culture were Byzantine. [Lowry 1986:259]

Thus, the stability of the First Ottoman period in the southern Mani Peninsula fits well within a general understanding of how religious landscapes might persist immediately after imperial collapse.

A few generations after a collapse like that of the Byzantine Empire, the religious landscape usually begins a process of metamorphosis: migrants and colonists bring new belief systems, different types of religious infrastructure are built, and conversion takes place as descendants of locals from the pre-collapse era are captivated by new ideas or find economic and political incentives to publicly change their faith. This kind of metamorphosis is exactly what took place in the rest 
of the Peloponnese and the Balkans, where multi-faith communities arose and group conversions to Islam or Catholicism were unexceptional events.

It is clear that such metamorphosis did not take place in the southern Mani Peninsula. The first indication of the immutability of its religious landscape comes from the period 1204-1261, when Frankish kingdoms were established throughout the Peloponnese and the rapid construction of Catholic churches reflected the complex multi-faith fabric of the time. In fact, Panayotidi (2005b:92) argued that through building new Orthodox churches, the local residents of Mani "demonstrated their resistance to the Latin conquerors." Neither in this period, nor in 1685-1715 when the Republic of Venice conquered the Peloponnese, did Catholic churches (or Catholic influences in architecture, portraiture of saints, etc.) appear in Mani's religious landscape. Additionally, emphasis was placed on the Orthodox Christian affiliation of the locals in the $18^{\text {th }}$ century, when hundreds of new churches were built and used as a part of daily life.

These findings beg the question: Why did the local residents of Mani so strongly adhere to their pre-collapse religious identity? One answer could be that religion is simply one aspect of a broader ethnic identity, and that the assertion of Orthodox Christianity was part of a larger effort to emphasize their difference from other people living in the Peloponnese (or Greece more broadly). Such an interpretation has good support from modern ethnographic studies and histories of the region (e.g., Andromedas 1976; Saïtas 2009).

At the same time, a deeper interpretation is both possible and necessary in order to help inform an archaeological understanding of the complex relationship between religion and power. In this case, the states that took control of Mani after Byzantine collapse were active proponents of a different religion, and conversion was one of several strategies that their representatives used to establish control over new territories. Political and economic incentives helped to ensure the loyalty and support of converts. In turn, this process helped to integrate the pre-existing local power structures into the state's administration, with the state having to invest relatively little effort or few resources in controlling its new territories.

In Mani, the low conversion rate and refusal to abide integration (for example, through the destruction of Ottoman colonies) stoked a turbulent political 
atmosphere. The state had a difficult time maintaining control over the region, in part because of its inability to establish channels of hegemonic power. It was left to rely solely on high-investment "territorial" strategies of tax collection, military involvement, and the construction and refurbishment of fortresses (see Hassig 1985; Hastorf and D'Altroy 2001:19-20) - none of which worked well in the long term because of the region's peripherality.

In this vein, the region's adherence to Orthodox Christianity may also be read as an attempt to undermine the hegemonic power of the Ottoman Empire and the Republic of Venice after they conquered the Peloponnese. More than simply affirming their ethnic difference, the maintenance of an Orthodox religious landscape through the construction and renewal of churches and the unwillingness to convert (or social pressure not to do so) were part of a counter-hegemonic response that allowed the locals to assert their independence from the new state and to uphold a kind of "negotiated peripherality."

Acknowledgments. Data were collected as part of a doctoral dissertation under the auspices of the 5th Ephorate of Byzantine Antiquities in Sparta. Research funding was provided by the National Science Foundation (BCS-1346694), ArchaeoLandscapes Europe, and the University of Illinois at Chicago. Funding for the writing phase was provided by a Marie Skłodowska-Curie Actions Individual Fellowship (H2020-MSCA-IF2016 750843). Special thanks to Evangelia Eleftheriou for assistance with permit requests, the staff at the Pikoulakis tower museum in Areopoli for granting access to churches, Chelsea Gardner and Billy Ridge for accompanying me in the field, and Tuna Kalaycı for providing comments on a draft of this paper. 


\section{References Cited}

Ameen, Ahmed

2017 Islamic Architecture in Greece: Mosques. Bibliotheca Alexandrina, Alexandria, Egypt.

Andromedas, John N.

1976 Maniat Folk Culture and the Ethnic Mosaic in the Southeast Peloponnese. Annals of the New York Academy of Sciences 268:199-206. DOI: $10.1111 / j .1749-6632.1976 . t b 47643 . x$.

Athanassopoulos, Effie F.

2016 Nemea Valley Archaeological Project. Vol. II: Landscape Archaeology and the Medieval Countryside. The American School of Classical Studies at Athens, Princeton, New Jersey.

Blundell Jones, Peter

2016 Architecture and Ritual: How Buildings Shape Society. Bloomsbury Academic, London.

Cassis, Marica, Owen Doonan, Hugh Elton, and James Newhard

2018 Evaluating Archaeological Evidence for Demographics, Abandonment, and Recovery in Late Antique and Byzantine Anatolia. Human Ecology 46:381398. DOI: $10.1007 / \mathrm{s} 10745-018-0003-1$.

Çelebi, Evliya

2011 [1685] Günümüz Türkçesiyle Evliya Çelebi Seyahatnâmesi: Gümülcine, Kavala, Selânik, Tırhala, Atina, Mora, Navarin, Girit Adası, Hanya, Kandiye, Elbasan, Ohri, Tekirdağı (8. Kitap: 1. Cilt) [Evliya Çelebi's Travelogue in Modern Turkish: Gümülcine, Kavala, Salonika, Trikala, Athens, Morea, 
Navarino, the Island of Crete, Chania, Candia, Elbasan, Ohri, Tekirdag (Book 8: Volume 1)]. Edited by Seyit Ali Kahraman. Yapı Kredi Yayınları, İstanbul.

Chatzidakis, Manolis

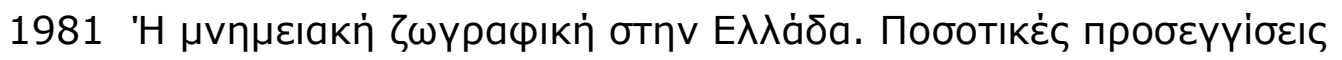

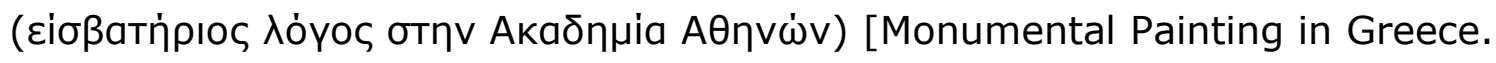
Quantitative Approaches (Entrance Speech at the Academy of Athens)].

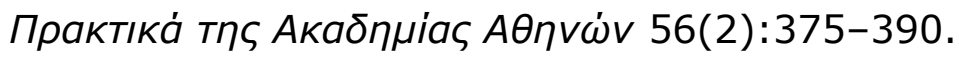

Cooper, Lisa

2006 The Demise and Regeneration of Bronze Age Urban Centers in the Euphrates Valley of Syria. In After Collapse: The Regeneration of Complex Societies, edited by Glenn M. Schwartz and John J. Nichols, pp. 18-37. The University of Arizona Press, Tucson.

Coşgel, Metin M.

2002 Ottoman Tax Registers (Tahrir Defterleri). Electronic document, http://digitalcommons.uconn.edu/econ_wpapers/200247, accessed February 23, 2020.

Deliyianni-Dori, Eleni

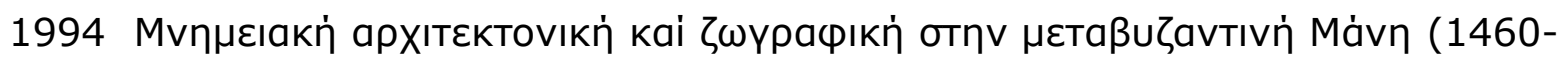
1830) [Monumental Architecture and Painting in Post-Byzantine Mani (1460-

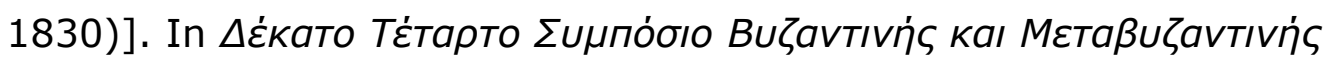

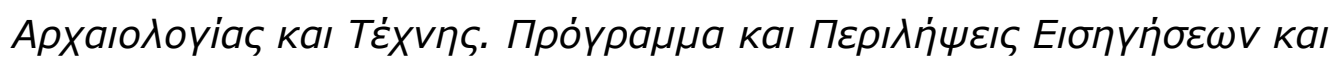

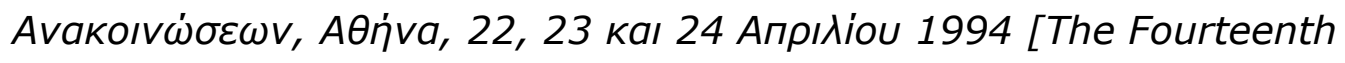
Symposium of Byzantine and Post-Byzantine Archeology and Art. Program and Summaries of Contributions and Announcements, Athens, 22, 23 and 24 April 1994]. Christian Archaeological Society (XAE), Athens.

2005 Post-Byzantine Mani (1460-1830). In Tales of Religious Faith in Mani, edited by Nikos Roumeliotis and Angeliki Mexia, pp. 33-42. Hellenic Ministry of Culture, Network of Mani Museums 2. Kapon Editions, Athens. 
Drandakis, Nikolaos V.

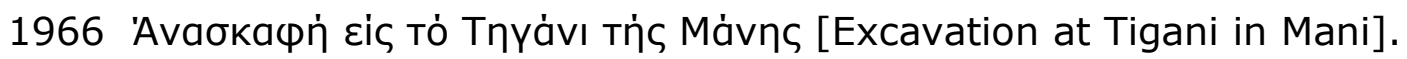

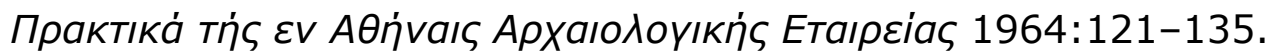

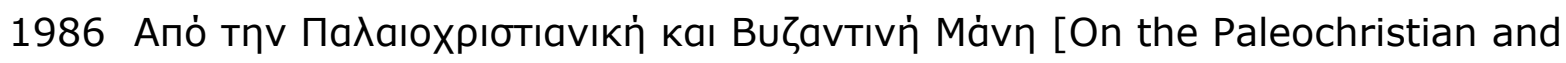

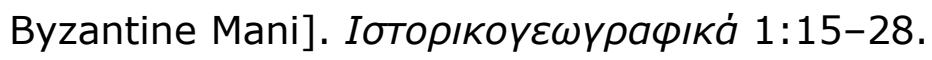

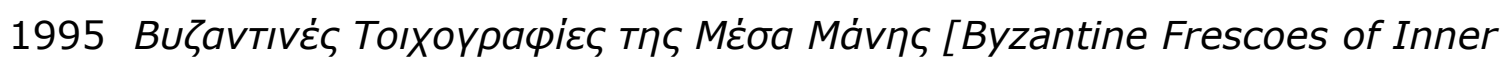

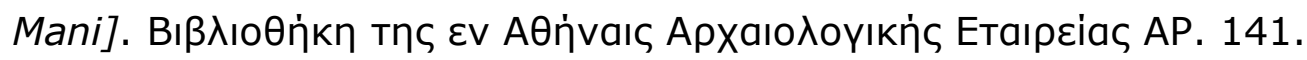

Archaeological Society at Athens, Athens.

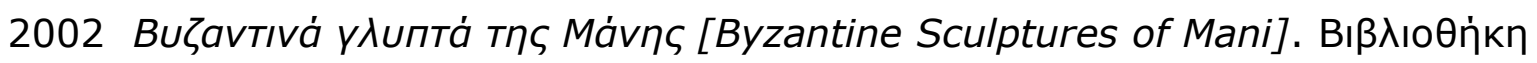

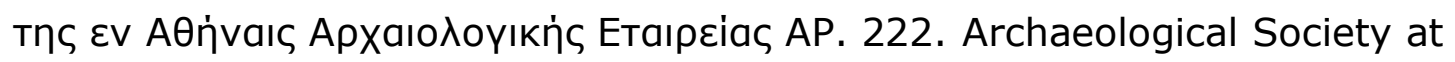

Athens, Athens.

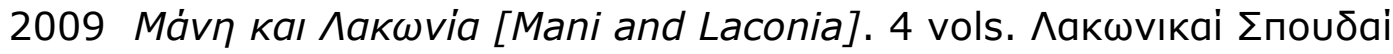

Пара́ртпна 17. Society for Laconian Studies, Athens.

Drandakis, Nikolaos V., Eleni Dori, Viktoria Kepetzi, and Maria Konstantoudaki

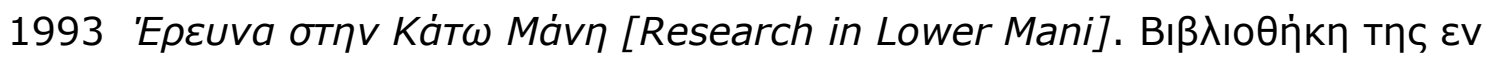

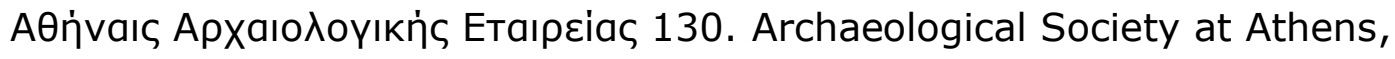
Athens.

Faulseit, Ronald K.

2015 Collapse, Resilience, and Transformation in Complex Societies: Modeling Trends and Understanding Diversity. In Beyond Collapse: Archaeological Perspectives on Resilience, Revitalization, and Transformation in Complex Societies, edited by Ronald K. Faulseit, pp. 3-26. Center for Archaeological Investigations Occasional Paper 42. Southern Illinois University Press, Carbondale.

Feinman, Gary M.

2016 Variation and Change in Archaic States: Ritual as a Mechanism of Sociopolitical Integration. In Ritual and Archaic States, edited by Joanne M. A. Murphy, pp. 1-22. University Press of Florida, Gainesville. 
Finlay, George

1877 A History of Greece from its Conquest by the Romans to the Present Time, B.C. 146 to A.D. 1864. Vol. 1. Clarendon Press, Oxford.

Gerstel, Sharon E. J.

2015 Rural Lives and Landscapes in Late Byzantium: Art, Archaeology, and Ethnography. Cambridge University Press, Cambridge.

Gkioles, Nikolaos

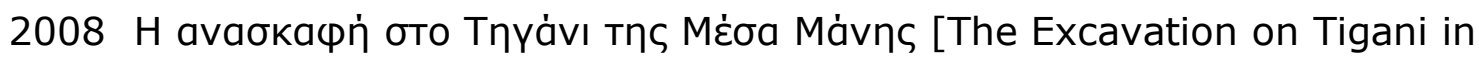

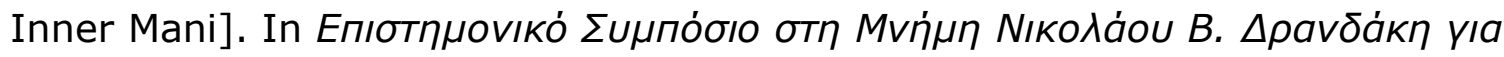

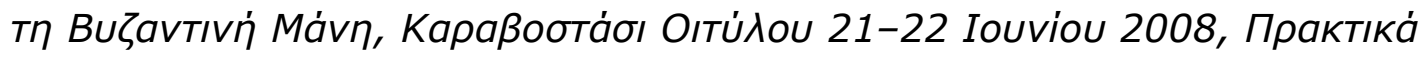
[Proceedings of the Scientific Symposium in Memory of Nikolaos V. Drandakis on Byzantine Mani, Karavostasi Oitylo, 21-22 June 2008], edited by Evangelia P. Eleftheriou and Angeliki Mexia, pp. 61-77. Ministry of Culture 5th Ephorate of Byzantine Antiquities, Deme of Oitylo, Sparta.

Graf, Tobias P.

2014 Of Half-Lives and Double-Lives: "Renegades" in the Ottoman Empire and Their Pre-Conversion Ties, ca. 1580-1610. In Well-Connected Domains: Towards an Entangled Ottoman History, edited by Pascal W. Firges, Tobias P. Graf, Christian Roth, Gülay Tulasoğlu, Halil İnalcık, and Boğaç Ergene, pp. 131-149. The Ottoman Empire and Its Heritage: Politics, Society and Economy 57. Brill, Boston.

Gregory, Timothy E.

2013 People and Settlements of the Northeastern Peloponnese in the Late Middle Ages. In Viewing the Morea: Land and People in the Late Medieval Peloponnese, edited by Sharon E. J. Gerstel, pp. 277-306. Dumbarton Oaks Research Library and Collection, Washington, D.C. 
Hassig, Ross

1985 Trade, Tribute, and Transportation: The Sixteenth-Century Political Economy of the Valley of Mexico. University of Oklahoma Press, Norman.

Hastorf, Christine A., and Terence N. D'Altroy

2001 The Domestic Economy, Households, and Imperial Transformation. In Empire and Domestic Economy, edited by Terence N. D'Altroy and Christine A. Hastorf, pp. 3-25. Interdisciplinary Contributions to Archaeology. Kluwer Academic/Plenum Publishers, New York.

Hellenic Ministry of Culture

2004 Settlements of Mani. Edited by Pari Kalamara and Nikos Roumeliotis. Network of Mani Museums 1. Kapon Editions, Athens.

2005 Tales of Religious Faith in Mani. Edited by Nikos Roumeliotis and Angeliki Mexia. Network of Mani Museums 2. Kapon Editions, Athens.

Kalamara, Pari, Iosif Efremidis, and Leda Moschou 2009 The Digital Mapping Programme of the Byzantine, Post-Byzantine and Modern Monuments of Mani and Ruined Byzantine Rural Settlements in Laconian Mani. British School at Athens Studies 16:369-370.

Kalopissi-Verti, Sophia

1999 Stylistic Trends in the Palaeologan Painted Churches of the Mani, Peloponnese. In Древнерусское искусство. Византия и Древняя Русь. К 100-летию Андрея Николаевича Грабара (1896-1990) [Ancient Russian Art. Byzantium and Ancient Rus. On the 100th Anniversary of Andrei Nikolayevich Grabar (1896-1990)], edited by E. S. Smirnova, pp. 193-209. DB, St. Petersburg.

2003 Epigraphic Evidence in Middle-Byzantine Churches of the Mani: Patronage

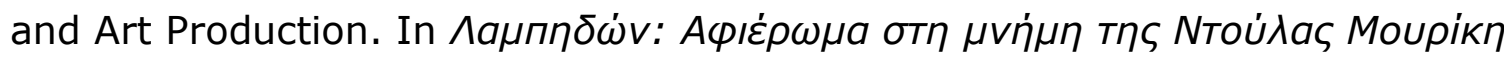
[Lampidon: Tribute to the Memory of Doula Mouriki], edited by Mary AspraVardavaki, pp. 339-354. NTUA University Press, Athens. 
2005 Patrons and Craftsmen in Mani during the Byzantine and Post-Byzantine Period. In Tales of Religious Faith in Mani, edited by Nikos Roumeliotis and Angeliki Mexia, pp. 99-109. Hellenic Ministry of Culture, Network of Mani Museums 2. Kapon Editions, Athens.

Katsafados, Panagiotis Stam.

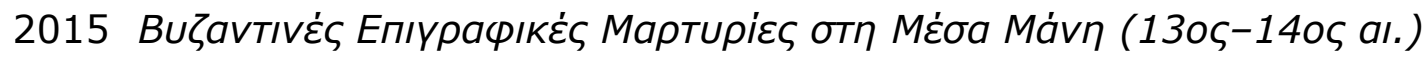
[Byzantine Inscriptions in Inner Mani $\left(13^{\text {th }}-14\right.$ th c.)]. Bibliotechnia, Athens.

Kardulias, P. Nick

2007 Negotiation and Incorporation on the Margins of World-Systems:

Examples from Cyprus and North America. Journal of World-Systems Research 13(1):55-82. DOI: 10.5195/jwsr.2007.359.

Kiel, Machiel

1999 The Ottoman Imperial Registers: Central Greece and Northern Bulgaria in the 15th-19th Century; The Demographic Development of Two Areas Compared. In Reconstructing Past Population Trends in Mediterranean Europe (3000 B.C. - A.D. 1800), edited by John Bintliff and Kostas Sbonias, pp. 195-218. Oxbow, Oxford.

Komis, Kostas

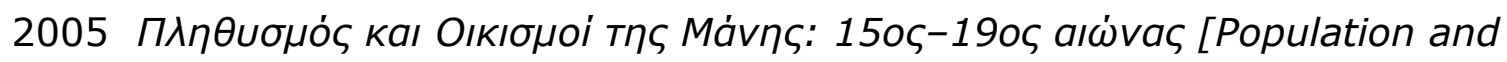
Settlements of the Mani: 15th-19th Centuries]. 2nd ed. University of Ioannina, Ioannina.

Kuecker, Glen David, and Thomas D. Hall

2011 Resilience and Community in the Age of World-System Collapse. Nature and Culture 6(1):18-40. DOI:10.3167/nc.2011.060102. 
Lowry, Heath W.

1986 The Island of Limnos: A Case Study on the Continuity of Byzantine Forms Under Ottoman Rule. In Continuity and Change in Late Byzantine and Early Ottoman Society: Papers Given at a Symposium at Dumbarton Oaks in May 1982, edited by Anthony Bryer and Heath Lowry, pp. 235-259. Dumbarton Oaks, Washington, DC.

Megaw, Arthur H. S.

1932-1933 Byzantine Architecture in Mani. The Annual of the British School at Athens 33:137-162.

Mexia, Angeliki

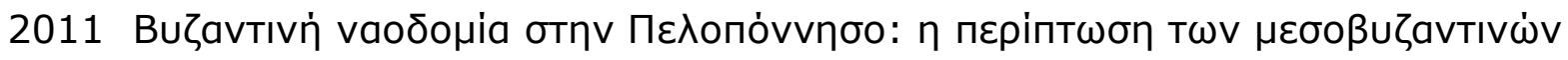

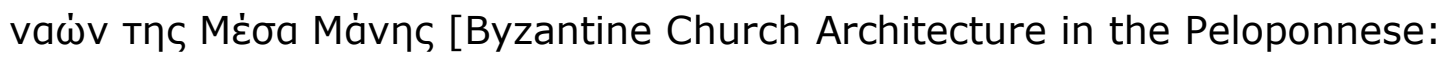
The Case of the Middle Byzantine Churches of Inner Mani], Vol B. Unpublished PhD, National and Kapodistrian University of Athens, Athens.

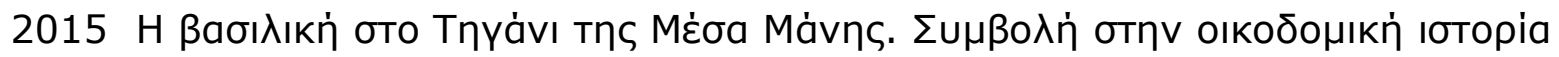
Tou vaoú [The Basilica at Tigani in Mesa Mani. Contribution to the Building

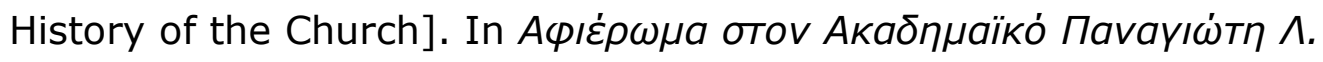
Вокото́почגo [Tribute to the Academician Panagiotis L. Vokotopoulos], edited by Vasilis Katsaros and Anastasia Tourta, pp. 57-66. Kapon Editions, Athens.

2016 Building Practices in the Helladic Province of Mani during the Komnenian Period: The Assimilation of the Prevailing Trends in Church Architecture. In Against Gravity: Building Practices in the Pre-Industrial World, edited by Robert Ousterhout, Dorian Borbonus, and Elisha Dumser. University of Pennsylvania, Philadelphia, PA.

Middleton, Guy D.

2017 Understanding Collapse: Ancient History and Modern Myths. Cambridge University Press, Cambridge. 
Minkov, Anton

2004 Conversion to Islam in the Balkans: Kisve Bahası Petitions and Ottoman Social Life, 1670-1730. The Ottoman Empire and its Heritage 30. Brill, Leiden.

Panayotidi, Maria

2005a Village Painting and the Question of Local "Workshops." In Les Villages dans I'Empire Byzantin (IVe-XVe siècle) [Villages in the Byzantine Empire (4th-15th centuries)], edited by Jacques Lefort, Cécile Morrisson, and JeanPierre Sodini, pp. 193-212. Réalités Byzantines 11. Lethielleux, Paris. 2005b Monumental Painting in the Churches of Mani - A Means of Expression and Communication. In Tales of Religious Faith in Mani, edited by Nikos Roumeliotis and Angeliki Mexia, pp. 85-97. Hellenic Ministry of Culture, Network of Mani Museums 2. Kapon Editions, Athens.

Papantoniou, Giorgos, and Athanasios Vionis

2017 Landscape Archaeology and Sacred Space in the Eastern Mediterranean: A Glimpse from Cyprus. Land 6(2):40. DOI:10.3390/land6020040.

Porphyrogenitus, Constantine 1985 [1967] De Administrando Imperio. Edited by Gy. Moravcsik. Translated by R. J. H. Jenkins. 2nd ed. Dumbarton Oaks Center for Byzantine Studies, Washington, D.C.

Saïtas, Yanis 2009 Social and Spatial Organization in the Peninsula of the Mani (Southern Peloponnese): Medieval, Post-Medieval and Modern Times. In Medieval and Post-Medieval Greece: The Corfu Papers, edited by John Bintliff and Hanna Stöger, pp. 133-152. BAR International Series 2023. Archaeopress, Oxford. 
Sanders, Guy D. R.

2015 William of Moerbeke's Church at Merbaka: The Use of Ancient Spolia to Make Personal and Political Statements. Hesperia 84(3):583-626. DOI: $10.2972 /$ hesperia.84.3.0583.

Schwartz, Glenn M.

2006 From Collapse to Regeneration. In After Collapse: The Regeneration of Complex Societies, edited by Glenn M. Schwartz and John J. Nichols, pp. 317. The University of Arizona Press, Tucson.

Seifried, Rebecca M.

2016 Community Organization and Imperial Expansion in a Rural Landscape:

The Mani Peninsula (AD 1000-1821). Unpublished PhD, University of Illinois at Chicago, Chicago.

Seifried, Rebecca M., and Tuna Kalaycı

2019 An Exploratory Spatial Analysis of the Churches in the Southern Mani Peninsula, Greece. Open Archaeology 5(1):519-539. DOI:10.1515/opar2019-0032.

Traquair, Ramsay

1908 The Churches of Western Mani. The Annual of the British School at Athens 15:177-213.

Vionis, Athanasios $\mathrm{K}$.

2012 A Crusader, Ottoman, and Early Modern Aegean Archaeology: Built Environment and Domestic Material Culture in the Medieval and PostMedieval Cyclades, Greece (13th-20th Centuries AD). Archaeological Studies Leiden University 22. Leiden University Press, Leiden. 
Vroom, Joanita, and Fotini Kondyli

2015 'Dark Age' Butrint and Athens: Rewriting the History of Two Early

Byzantine Towns. In Medieval and Post-Medieval Ceramics in the Eastern Mediterranean - Fact and Fiction. Proceedings of the First International Conference on Byzantine and Ottoman Archaeology, Amsterdam, 21-23 October 2011, edited by Joanita Vroom, pp. 317-342. Brepols, Turnhout.

Wallerstein, Immanuel

1974 The Modern World-System I: Capitalist Agriculture and the Origins of the European World-Economy in the Sixteenth Century. Academic Press, New York.

Williams, Patrick Ryan, and Donna J. Nash

2016 Religious Ritual and Wari State Expansion. In Ritual and Archaic States, edited by Joanne M. A. Murphy, pp. 131-156. University Press of Florida, Gainesville. 